\title{
Exceptional and Futureless Humanitarian Education of Syrian Refugees in Lebanon: Prospects for Shifting the Lens
}

\author{
CATHRINE BRUN AND MAHA SHUAYB ${ }^{1}$
}

\section{Abstract}

The article unpacks and analyzes the potentials and shortcomings of a humanitarian framework for educational response during protracted displacement. Humanitarianism is concerned with the immediate, while education is future oriented. Calls to shift the humanitarian discourse from relief and survival to development have contributed to include education as part of the humanitarian response. The article analyzes potentials and limitations in Lebanon's education provision and policies for Syrian refugees. We discuss the impact and implications of the humanitarian response and reflect on what principles should be formulated for provision of a socially just, inclusive, and more developmental education for refugees in protracted displacement.

\section{Résumé}

Cet article décortique et analyse les lacunes potentielles d'un cadre humanitaire pour les réponses éducatives au déplacement prolongé. L'humanitarisme se préoccupe de l'immédiat alors que l'éducation est une activité orientée vers l'avenir. Les appels à faire passer l'accent du discours humanitaire du secours et de la survie au développement ont contribué à l'inclusion de léducation dans l'intervention humanitaire. Cet article analyse le potentiel et les limites de loffre et des politiques éducatives pour les réfugiés syriens au Liban. Nous discutons de leffet et des ramifications de la réponse humanitaire et réfléchissons aux principes qui devraient être formulés pour une offre éducative socialement juste, inclusive et davantage axée sur le développement pour les réfugiés en situation de déplacement prolongé.

1. Equal authorship. The research is funded by the United Kingdom's ESRC (Es/soo4742/1) and Canada's IDRC (109043-001) on Trajectories from Education and Employment of Young People in Lebanon and Jordan in the Context of Protracted Displacement. Many thanks to Samira Chatila and Nader Ahmad for assisting with the policy analysis.

(C) Cathrine Brun and Maha Shuay, 2020. This open-access work is licensed under a Creative Commons Attribution-NonCommercial 4.0 International Licence, which permits use, reproduction, and distribution in any medium for non-commercial purposes, provided the original authorship is credited and the original publication in Refuge: Canada's Journal on Refugees is cited.
Cette œuvre en libre accès fait l'objet d'une licence Creative Commons Attribution-NonCommercial 4.0 International License, laquelle autorise l'utilisation, la reproduction et la distribution de l’euvre sur tout support à des fins non commerciales, pourvu que l'auteur ou les auteurs originaux soient mentionnés et que la publication originale dans Refuge: revue canadienne sur les réfugiés soit citée. 


\section{Introduction}

$\mathrm{O}$ ver the past decade, Lebanon witnessed one of the largest influxes of refugees relative to its population. Education is a main pillar in the humanitarian response to the refugee crisis but has been severely tested as Lebanon became the country with the highest percentage of refugees per capita in the world. After almost a decade of providing education intervention for over 500,000 Syrian school-aged refugee children in Lebanon, still less than $2 \%$ are enrolled in grade 9 , and $4 \%$ in grade 12 . Over $40 \%$ of Syrian school-aged children are out of school or have never been enrolled (Norwegian Refugee Council, 2020). Hundreds of millions of dollars have been invested, and the poor outcome signifies grave injustice and inequality. In this article we aim to investigate the impact of adopting the humanitarian model to provide education for Syrian refugees in Lebanon.

Education leads to increased well-being among primary and secondary school children in refugee settings (Burde et al., 2017). Education in a conflict setting has also been a priority in promotion of mutual understanding, peace, and tolerance, and prevention of violence and conflict (UNESCO 2000, in Kagawa, 2005, p. 489). As a result, the Education in Emergency (EiE) framework, which is embedded in a humanitarian paradigm, is flourishing, but its impact, strength, and limitations have not been sufficiently addressed. We aim to unpack and critique the model by using Lebanon as a case study in order to understand the implications of adopting the humanitarian model when providing education in protracted refugee situations. In particular we analyze the recent transition in the humanitarian education discourse to accommodate refugees within national educational systems. Syrian refugees in Lebanon were admitted to public schools mostly in segregated shifts and had to follow the Lebanese national curriculum. In this article we delve into the implications of following the humanitarian education paradigm within the national education system in Lebanon. A discourse on moving from a humanitarian towards a development approach has framed the policy transitions in Lebanon, but education for refugees is still firmly placed within a humanitarian approach. We also identify the priorities within the principles of humanitarian education and how it is integrated into a national response. While current approaches have focused on increased access to education, we question whether this leads to more equal and socially just outcomes and highlight the tensions between frameworks like the global Emergency in Education framework and the national educational framework and reflect on their advantages and disadvantages.

As the discourse shifts from a humanitarian to a development model, we analyze the evolvement and impact of education policies for Syrian refugees in Lebanon and reflect on the inequalities that are produced within the system that continues to follow a humanitarian approach. The article contributes to the increasing body of scholarship on emergency education, and on education in protracted refugee situations (Burde et al., 2017; Dryden-Peterson et al., 2019; Ferfolja, 2009; Sidhu \& Taylor, 2007). In order to understand how the humanitarian model shapes education policies and provisions in protracted crises, we first analyze the relationship between a humanitarian discourse and approaches to emergency education and to emergency education's relation to education more generally. We then examine the strengths and limitations of education in the emergency model in Lebanon and analyze how the education policies for Syrian refugees shifted. We consider the impact of current policies at micro, meso, and macro levels. Finally, we reflect on potential ways to rethink a system for higher-quality, inclusive, and just education for refugees in protracted conflict.

\section{Education in the Humanitarian Context}

In order to understand the discourse of education in a humanitarian setting, this section unpacks the logic behind the two discourses and their potential and limitations in providing an effective framework for education of refugees.

\section{Humanitarian Reason}

The motivation for humanitarianism is saving strangers (Fassin, 2012). Its moral sentiments are grounded in the principles of humanity, neutrality, impartiality, and independence, as formulated for International Red Cross and Red Crescent movements. Humanitarian assistance is not lasting. It is embedded in the temporary: saving lives in the short term. Humanitarianism is also political, and its principles are utilized as a strategy for host states such as Lebanon to maintain their view that refugees-even in protracted displacement -are not supposed to stay: the only assistance acceptable is based in a temporary and relief-based approach. In a humanitarian discourse, people are not first and foremost citizens. They are victims who are temporarily present, often passive, powerless, and without agency. However, for refugees who may be present in a host state for 10 or 20 years or more, their temporary status becomes a permanent impermanence that shapes the possibility of developing lives and creating a future at the place of displacement or elsewhere (Brun, 2003, 2016).

With protracted displacement, humanitarian actors increasingly operate where humanitarian temporality and principles are placed under pressure. These developments have been accompanied by a discourse on a humanitariandevelopment nexus. However, few consequences of this shift can be identified in humanitarian practice (Knox Clarke, 2018), partly because there is a limited understanding of what development might mean in this context. A development approach needs to operate with a longer time frame, attack 
the roots of inequality, and create a more inclusive approach by accepting the presence of refugees at the place of displacement (Schmidt, 2019). Education, to which we now turn, is a pertinent field to think through what development might mean in this context.

\section{Emergency Education}

Education for refugees is dominated by humanitarian reasons, as explained above. The most common framework for education of refugees, the Education in Emergency framework (EiE), established by the Inter-Agency Network for Education in Emergencies (INEE), states that it is embedded in the humanitarian paradigm (INEE, 2010). This framework has proliferated during the past 10 years and has been translated into 20 different languages. The standards have also been adapted in 11 countries, including Lebanon.

Education in emergency is embedded in a human rights philosophy, in particular the Convention on the Rights of the Child, Education for All, and the Humanitarian Charter. From the minimum standards in the INEE framework, emergency is defined briefly as a situation where a community has been disrupted and has yet to return to stability (INEE, 2010, p. 117). "Emergency education" is defined as the provision of quality education opportunities that meet the physical protection, psychosocial, developmental, and cognitive needs of people affected by emergencies, which can be life-sustaining and life-saving.

Yet tensions between education and humanitarianism and their differing aims often surface in discussions about themes such as the curriculum that should be taught, the language of teaching, the accreditation and certification of learning, who should offer this education, and the role of the hosting state versus humanitarian agencies. For example, a 2004 INEE report notes, "[F]or refugees, it is preferred to adopt the curricula of the country of origin to facilitate voluntary repatriation" (INEE, 2004, p. 57). Since the 1980s, repatriation to one's home country became the focus of refugee policies, despite limited possibilities of return (Chimni, 2004). Emphasis on return has resulted in short-term education that is devoid of a coherent strategic vision for students' future prospects. Consequently, families or individual students lack the incentive to enrol in an education program that offers little preparation for further higher education or employment in the host country. The temporality of the situation and the absence of prospects were overwhelmingly cited as reasons that families avoided enrolling their children in schools (Shuayb et al., 2016).

Linked to the short-term and temporary, education in emergencies does not take into consideration what education is for and tends to treat it as an unmitigated good (Lynch, 2006). While education leads to increased well-being among primary and secondary school children in refugee settings and helps children and young people to have aspirations for the future (Burde et al., 2017; Dryden-Peterson, 2016), the legal status of refugee children is different from the status of the non-displaced, and in countries like Lebanon, the possibilities that they will realize their aspirations are more limited than for their non-displaced peers because they cannot access all types of employment.

Another shortcoming of the emergency model is its highly de-politicized approach to refugee education, because, in contrast, the subject of refugee reception is extremely politicized. Additionally, in emergency education frameworks, refugees from war zones and people fleeing natural disasters such as hurricanes are treated with the same approach. There is a failure to acknowledge that most conflicts are protracted, while other disasters have a varying time scale. Moreover, a political conflict is rarely restricted to one geographical area: the conflict is often mitigated by other parties who also influence the kind of support offered in a particular reception context.

\section{The Tensions in Emergency Education: A Schema}

Education is a long-term planned process that prepares children for the future. As such it speaks directly to a development approach to protracted displacement. Education during displacement helps children maintain aspirations for the future. In the same way, governments often compose their educational policies and strategies with the future in mind, for the job market, nation-building, or individuals' self-actualization. "Emergency education" is thus clearly an oxymoron that expresses tensions between education and humanitarianism. Here we compare the logic of humanitarianism, education, and emergency education to identify potential overlaps and tensions. While we discuss general principles of humanitarianism, education, and emergency education, we do not address the multitude of paradigms and schools of thought that might be behind these principles. Table 1 compares the logic of the three.

Table 1 summarizes the main discourse of the humanitarian model and how it is translated into education in general, and in emergency settings in particular. The EiE initiative also offers a global framework for thinking and implementing education interventions for refugees. This is an essential role for providing guidance for UN agencies and host countries. Interestingly, there has been a shift in EiE discourse in favour of implementing this framework but within the national education system of the host country. Yet the strengths and limitations of this shift are yet to be examined. In the next section we analyze the outcome of humanitarian education in Lebanon-particularly the education response and how it changed during the crisis between 2011 and 2018. 


\section{Table 1. The Logic of Humanitarianism, Education, and Emergency Education}

\begin{tabular}{|c|c|c|c|}
\hline Logic (ideal) & Humanitarianism & Education & Education in emergency \\
\hline $\begin{array}{l}\text { Motivation/ } \\
\text { objective }\end{array}$ & Saving lives & $\begin{array}{l}\text { Employment, building/mak- } \\
\text { ing good citizens, empower- } \\
\text { ment, self-actualization }\end{array}$ & $\begin{array}{l}\text { Literacy, a human rights } \\
\text { obligation }\end{array}$ \\
\hline Time frame & Present & Past, present, and future & $\begin{array}{l}\text { Temporary, awaiting } \\
\text { repatriation }\end{array}$ \\
\hline $\begin{array}{l}\text { Understanding the person/ } \\
\text { individual }\end{array}$ & Biology, saving lives & Biography, recognition & Individual, saving lives \\
\hline Participation & $\begin{array}{l}\text { Passive victims, to be } \\
\text { offered assistance }\end{array}$ & $\begin{array}{l}\text { An entitlement, participa- } \\
\text { tion in decision making } \\
\text { concerning education for } \\
\text { community and children }\end{array}$ & $\begin{array}{l}\text { Passive and conditional, low } \\
\text { sense of entitlement: educa- } \\
\text { tion as assistance }\end{array}$ \\
\hline Social space & $\begin{array}{l}\text { Exceptional spaces of } \\
\text { assistance }\end{array}$ & National & $\begin{array}{l}\text { Different degrees of segre- } \\
\text { gation/ integration }\end{array}$ \\
\hline Objective & Relief & Development & Temporary protection \\
\hline $\begin{array}{l}\text { Status, citizenship, } \\
\text { membership }\end{array}$ & $\begin{array}{l}\text { Humanitarian labels, catego- } \\
\text { ries of need }\end{array}$ & $\begin{array}{l}\text { Right to education as } \\
\text { citizens and full members of } \\
\text { society }\end{array}$ & $\begin{array}{l}\text { Conditional right to educa- } \\
\text { tion depending on host } \\
\text { country, with suspended } \\
\text { civic rights }\end{array}$ \\
\hline Human rights & Right to life & $\begin{array}{l}\text { Basic human rights, Conven- } \\
\text { tion on the Rights of the } \\
\text { Child }\end{array}$ & $\begin{array}{l}\text { Right to education detached } \\
\text { from other rights }\end{array}$ \\
\hline
\end{tabular}

\section{The Dynamics of Humanitarianism and Education in the Syrian Refugee Crisis in Lebanon}

The research presented below is based on a content analysis of educational policies, strategies, legislation, reports, statistics, and minutes of the Education Working Group published between 2011 and 2018. An analytical framework that examines the key aspects and processes in the education of refugees and how it evolved during these 8 years was developed and used to code and analyze the data, using Nvivo software. This section summarizes the main developments we identified from the analysis. Three stages distinguish the education response in Lebanon from an emergency stage, where humanitarian organizations were in the lead, to a shift towards a government response and development discourse. In particular, we examine the different policies and the education strategies "Reaching All Children with Education I and II" (RACE), which were developed to support the enrolment of Syrian refugee children in public schools in Lebanon while strengthening the national education system. Before we describe the stages of the response, we will introduce some background information on the Lebanese educational system and provisions to enrol Syrian refugees in education in Lebanon.

\section{Syrian Refugees and Education in Lebanon}

The 2011 protests in Syria transformed into a long-term and ongoing war, with repercussions well beyond the nation's borders. According to the United Nations High Commissioner for Refugees (UNHCR), the number of Syrians fleeing the war in Syria is more than 5 million worldwide (UNHCR, 2019). The number of Syrians registered as refugees in Lebanon is estimated to be 1 million, meaning that one in five people in Lebanon is a Syrian refugee.

Lebanon is not a signatory of the 1951 Un Refugee Convention and, at the time of writing in 2020, withholds refugee status from Syrians in Lebanon. Although the Lebanese government has permitted the UNHCR to register refugees, that protection is limited. It does not grant refugees the right to seek asylum or have any legal stay or refugee status (UN, 2015). 


$\begin{aligned} & \text { Table 2. Number of Syrians Enrolled in } \\
& \text { Morning and Afternoon Shifts } 2011-2018\end{aligned}$
\begin{tabular}{lrrr} 
Number of enrolled & $\begin{array}{r}\text { Morning } \\
\text { shift }\end{array}$ & $\begin{array}{r}\text { Afternoon } \\
\text { students }\end{array}$ & Total \\
\hline $2011 / 12$ & 30,000 & - & 30,000 \\
$2012 / 13$ & 29,000 & - & 29,000 \\
$2013 / 14$ & 58,360 & 29,902 & 88,262 \\
$2014 / 15$ & 44,000 & 62,000 & 106,000 \\
$2015 / 16$ & 62,500 & 92,595 & 155,095 \\
$2016 / 17^{\text {a }}$ & 63,754 & 157,868 & 221,622 \\
$2017 / 18^{\text {b }}$ & 59,145 & 154,209 & 213,354 \\
\hline
\end{tabular}

Note: Compiled from RACE II PMU online platform.

a RACE PMU (2017). Note that another report from the same source dated July 2018 states that the enrolment rate in the afternoon shift in $2016 / 17$ was only 124,000 (RACE PMU 2018a).

${ }^{b}$ RACE PMU (2018b).

Lebanon's most recent memorandum of understanding with the UNHCR (2008) declares that "Lebanon does not consider itself an asylum country," and, under its mandate, the UNHCR carries out all refugee status determinations. A discourse of return has increased in prominence over the past year which follows a politicized discourse of temporariness related to the Palestinian refugees residing in a temporary status in the country since 1948 and the diverging relationships among political parties to the conflict in Syria.

In 2016, UNHCR estimated that Syrian school-age children in Lebanon totalled 488,832 (MEHE, 2016). The Lebanese government committed to compulsory education for children under 15 years old by opening up Lebanese public schools to Syrian refugees. However, the enrolment rates among Syrian refugees in formal education does not exceed 40\% (MEHE, 2016), with only $1 \%$ enrolled in grade 9 (RACE PMU, 2019).

Despite inconsistency in the number of enrolled students reported by the Ministry of Education and Higher Education (MEHE) itself, Table 2 shows that there has been continuous progress. However, while retention rates have increased, the dropout is still very high (RACE PMU, 2018a). ${ }^{2}$

In the following section we track developments of the educational discourse and provisions for Syrian refugees in Lebanon. This response comprises three main stages.
Stage 1: The Humanitarian Crisis, Establishing an Education Response

With the influx of Syrian refugees in 2012, the MEHE allowed Syrian refugees to register in public schools, introducing several education policy initiatives for Syrian refugees. The ministry had not yet comprehended the scale of the crisis, saying that the UN's estimated increased demand on public schools was exaggerated (UNICEF, 2013). In 2013, the enrolment rate of Syrian school-age children in Lebanon was estimated at just $31 \%$. Refugees resided predominantly in some of the most deprived areas in Lebanon, where demands by the local community on public schools were higher than other areas. This period witnessed substantial involvement by humanitarian organizations and NGOs, including an adaptation of the EiE framework to Lebanon. Adaptation of the standards involved representatives of the Lebanese government, INGOS, UNRWA, and local Lebanese NGOs. However, Syrian NGOs and representatives from the refugee community were almost entirely absent.

A major policy that left a stark effect on enrolment was the introduction of two shifts in 2012-2013. MEHE introduced afternoon shifts reserved strictly for non-Lebanese students and requested funding from UN agencies to run shifts in order to absorb a larger number of children in education.

Several policy documents were issued during this period to provide education and support for refugees, such as "No Lost Generation" (2013), advocating for the priorities of children and youth. In 2013, the Lebanese Council of Ministers issued Decree 62 and memos 2 and 192 that allowed Syrian and Palestinian students from Syria to write the official exams in grades 9 and 12, provided that they submitted legal status documents of registration with UNHCR and previous school records.

At the end of 2014, the state stepped in to coordinate planning and implementation of the education response. Our analysis of those plans reveals an emphasis on increasing access to education for Syrian refugees by increasing capacity of the MEHE to absorb more children and removing legal barriers. People's legal status affected access to assistance and limited refugees' mobility, undermining families' capacity to reach schools without need to cross a security checkpoint and risk arrest.

One main feature of RACE I is its emphasis on access to education, because a large number of Syrian children were out of school and had to be enrolled. While the document discusses challenges to the quality of schooling, there were no attempts to address the structural issues that affected the

2. The success rate of Syrian children in the second shift increased in the official exams in grade 9 ( $72 \%$ in $2017-18$, compared to $66 \%$ in the previous year), and grade 12 (90\% in 2017-18, compared to $81 \%$ in the previous year) (RACE PMU, 2O18a). 
quality of schooling. In fact, the policy-makers' discourse reflects this emphasis on access rather than quality. The focus on access rather than quality was reflected in the staffing policy of the second shift, where priority was given to teachers working in the morning shift if they wished. There was no discussion of the impact of this additional workload on the quality of learning in both shifts.

One challenge to the schooling experience of nationals and refugees has been the Lebanese curriculum, developed in 1997, yet unaddressed in RACE I. In particular, the teaching of math and science in English or French has been behind the high dropout rates for Lebanese and Syrian children alike (UNICEF, 2013). During the first two years, Syrian refugees had difficulties adjusting to the Lebanese curriculum, in which most subjects are taught in English or French. Syrian refugees were demoted several grades because they had poor command of both languages (Shuayb et al., 2014).

\section{Stage 2: Government Hegemony, the Donor Community, and the Role of Migration to Europe}

As the Syrian crisis became protracted, policy began to change. The Lebanese government and MEHE led the education response in 2014 by introducing the Reaching All Children in Education (RACE I) initiative (MEHE, 2014) and froze most work done by NGOS in the public sector. The three-year, Us $\$ 6$ million program aimed at the 413,000 school-aged children (3-18 years) affected by the Syrian crisis. The initiative aimed to (1) ensure equitable access to educational opportunities; (2) improve the quality of learning and teaching; and (3) strengthen national policies, the educational system, and monitoring and evaluation (Government of Lebanon \& UN 2014, 2018; MEHE 2014, 2016).

Development of RACE I was led by MEHE and UN agencies-UNICEF in particular. However, at this time MEHE expressed its discontent with the work of some in the international and local non-governmental community, froze the work of the Regional Education Working Group chaired in turns by UNICEF and UNHCR, and presented itself as the main provider of education for refugees and receiver of donations. As a result, most non-formal ${ }^{3}$ education programs were frozen by MEHE, and NGOs were denied access to public schools. MEHE became almost the sole provider of formal education for refugees, and many non-formal education programs were brought to a halt. At this point MEHE introduced school shifts only for Syrian refugee children, who were offered four hours of learning from 2 to 6 p.m. Children learned maths, science, Arabic, and English, in addition to social studies, with a very short break in between. Students did not learn any other subjects, such as physical education or art. MEHE received $\$ 300$ from the international donor community for every Syrian child attending the morning public school shift and $\$ 600$ for the afternoon shift.

An overview of MEHE's policies at this stage shows a strategy to hold all strings to funding and education. While there are advantages to having a strong policy-maker lead formal education for refugee children, MEHE's policies had many limitations that had a stark effect on the future of refugees. The decision of the UN and donors to limit all their efforts to enrol children in formal public schools meant that thousands of children could not find vacant places to register.

RACE I aspired to reach 200,000 children in formal education. However, to absorb all school-aged refugee children, MEHE needed to at least triple its capacity, and that was not possible. Interviews with UNHCR and UNICEF officials reflected their frustrations with the restrictions that MEHE placed on them, especially on partnerships with the private sector and NGOS to increase access to education. The longer children spent time out of school, the harder and more expensive it became to enrol again.

RACE I was a humanitarian model for education: it was short term and it assumed repatriation would occur, so investing in the future through education was absent. Instead, emphasis was placed on enrolment in basic education, and creating barriers such as curriculum adaptation required legal documentation, language provisions, segregation, transport, remedial support, cost of post-basic education, official exams policy, higher education, and employment persist. References to secondary and higher education were scarce in RACE I. While some of these issues fall within the remit of the work of MEHE, others such as legal papers are part of a larger political debate that rests with the government. That brings us to another limitation, mentioned above, about the apolitical nature of the humanitarian response.

Some additional observations can be made about RACE I. Segregation of Syrian children in second shifts became normalized and had an impact on the possibilities of social cohesion in the long run. While second shifts were a necessity in some areas because capacity was limited, they contributed to escalating friction between the Lebanese and Syrian student populations (Shuayb \& Ahmad, in press).

\section{Stage 3: From Humanitarian to Development and Sustainability}

Inspired by the increased enrolment of Lebanese children in public schools, compared to pre-crisis levels, and the inclusion of more than $42 \%$ of school-age refugee children, RACE

3. Non-formal education refers to all educational programs, including psycho-social, remedial, and accelerated learning programs implemented by NGOs. Some were taking place on the school campus or after school. 
II was developed in 2016 (MEHE, 2016). RACE II, a 5-year sequel to RACE I, envisaged a more strategic approach with greater affinity for "development" and "stabilization" (MEHE, 2016). While the concepts of stabilization and development are not defined in the plan, the attempt to move away from a humanitarian approach is evident in its aims and objectives. This was partly prompted by the duration of the conflict and the pressure on the local community, which made development more pertinent.

In RACE II, MEHE has a central role in improving education of all vulnerable children-Lebanese or Syrian - while the donor's role is confined to funding and building the capacity of MEHE, which is responsible for planning and implementation.

In defining the shift from a humanitarian model to development, RACE II states, "While maintaining the humanitarian dimension of the Syria crisis response, strategic shifts need to occur towards longer-term approaches that cater for the protracted nature of the crisis. This requires the strengthening of the Lebanese public education system" (MEHE, 2016, p. 11).

RACE II suggested a revision of the national curriculum, as the existing one had not been revised since 1997. This reform would apply to all children attending schools, particularly public schools. Yet the new curriculum has not yet been finalized. RACE II did not discuss how the curriculum could address acculturation challenges that face refugees due to the nationalistic approach to designing the Lebanese curriculum and textbooks.

While secondary education was mentioned in RACE I, its presence as an objective in RACE II is more apparent. Vocational education continues to be overlooked in RACE II and is mentioned only once as an objective. Access to higher education is not mentioned in either RACE I or II. As for the second shift, it is seen as a success story that helped increase enrolment.

Compared to RACE I, RACE II focuses more on retention and the quality of education in both shifts. However, similar to RACE I, RACE II approaches nationals and refugee populations as two distinct groups. Sustainable development such as curriculum reform and vocational education seemed to target the Lebanese population, while the focus on refugees was on improving enrolment and retention. In other words, development was for the Lebanese while a humanitarian response was the focus of refugee-targeted interventions.

\section{Refugee Education in a Humanitarian Setting: Purposeless, Exceptional, and Segregated}

As we have shown so far, despite its shift in discourse from humanitarian reason to long-term development, education and education policies for refugees in Lebanon continue to operate with a short-term logic with several implications.
Here, we offer some lessons at the micro, meso, and macro levels.

\section{Micro: Education Implemented and Experienced in Schools}

Education for refugees as seen through RACE I and II is concerned primarily with the micro questions of providing education for refugees: the number and types of shifts, official exams policies, documents required, etc. One of our criticisms is that although work at the micro level is important, it is not accompanied by reflection on the purpose of this education and how it might prepare children for their future. This short-term vision is not restricted to the Lebanese experience but is also evident in humanitarian education in general (Dryden-Peterson et al., 2019).

Our second criticism of the Lebanese experience stems from the exceptionality outlook, in which these provisions were embedded. MEHE's argument for exclusion has been to increase access and to accommodate the needs of refugees. However, segregation hindered the educational attainment of Syrian refugees. Moreover, the challenges that Syrian refugees experience in the Lebanese educational system are similar to those of their Lebanese peers. The structural barriers and poor-quality education that Lebanese children in public schools have long suffered from were underplayed as challenges that needed to be addressed for both student populations.

\section{Meso: Actors' Role in Developing Education Policies and Provisions for Refugee Children}

The meso level is concerned with how education policies for refugees have been developed by humanitarian agencies, donors, and the state. As we showed above, the government, and MEHE in particular, took over from humanitarian agencies and led the response to provide education for refugees. The donor community largely stood by the Lebanese government and funded the education response in an attempt to stabilize the situation and curb the influx of refugees fleeing to Europe. As a result, the Lebanese government gained a stronger grip on the humanitarian response and compromised the education enrolment and attainment of refugees further without major objection from international actors or agencies. Policies in Lebanon may not conform to minimum standards such as INEE, but the response largely continued to follow a humanitarian logic: it was an exceptional response based on a logic of temporary presence. A more effective response could have been to provide education through all existing routes, including private, public, and NGOS, which could have resulted in higher enrolment and retention rates, as well as better quality education and less segregation. 
Lebanon's private sector absorbs $70 \%$ of students. ${ }^{4} \mathrm{Had}$ the response capitalized on both sectors, there could have been better chances to absorb higher numbers in a less segregated manner and with a more relational and holistic approach to education for refugees. However, MEHE insisted that it remain the only provider of schooling for Syrian children, blocking any attempts to involve the private sector in providing formal and accredited education. It also shut down most non-formal programs led by NGOs in the second and third years of the crisis. While obtaining an accredited school certificate was seen as a necessity and a key reason for investing in the public formal sector, the Syrian experience in Lebanon shows that it has little value if the quality of the schooling experience and the basic rights and quality of life are poor.

\section{Macro}

We understand the macro as the global world view that encompasses the principles, and ideals underpinning the policies and practices of education for refugees. The Lebanese experience offers insight into the tensions between the national and the global. MEHE pushed for segregated schooling for refugees. It insisted on the Lebanese curriculum and textbooks for sovereignty reasons. MEHE was already suffering from underperformance and low-quality education. Was it wise to invest in the national Lebanese public sector rather than a more hybrid system that could include provision of education offered by additional parties?

Crucially, humanitarian actors are seldom willing to undermine and challenge the sovereignty of the state and restrict themselves in questioning state policies. Yet transferring all responsibility to the state, which has underperforming systems and lacks transparency, is also a problem. At the moment, humanitarian actors can put limited pressure on the Lebanese state or provide technical guidance on how to best accommodate the needs of refugees. Here lies the importance of having global standards for countries that encourage more diverse and multi-sectoral responses rather than opting for hegemonic policies.

\section{Towards "Participatory and Socially Just" Frameworks for Education in Protracted Displacement}

The discourse on education in refugee settings, including in Lebanon, is dominated by a liberal discourse where access is the prime focus. Inequalities seldom feature in the discourse of education for refugees. Emphasis on access does not solve the potential for individual and societal development that is helped by the education system because the system is not based on equality and justice, nor on participation. In Lebanon, we have identified a system that is exceptional, offers education of poor quality, and promotes segregation and inequality of outcomes. In the current system and policies, there are modest attempts and limited willingness to target the root causes of this injustice and develop an improved system for all groups in the country-a system that may facilitate development in broader terms. Thus we suggest there is need to think beyond the simple school provisions of a classroom space and take one step back to question the philosophy of the whole process. There is need to reflect on how to overcome confinement of exceptionality in "refugee" status and a humanitarian reason to offer a holistic approach that is oriented towards the future. A commitment to education for a future requires a shift of paradigm from a "survival" and a "minimum" discourse to encompass access where Syrian refugees participate on par with others (Fraser, 2005).

Such a paradigm shift in education has potential for refugees and for the host community. Most refugees reside in low-income countries, where there are inherited inequalities in the host country that need to be addressed. However, refugee intervention paradigms overlook these injustices within a system that contributes to marginalization of parts of the local community and the newcomers. We do not suggest that providing better and more relevant education for refugees is easy. The political constraints are often almost impossible to overcome. On the basis of our conceptual discussion and the experience from Lebanon, we have identified a need to explore a two-pronged approach: a global framework that operates within the nation state framework.

First, where exceptionalism and futureless education dominate as the result of political unwillingness to integrate, some refugees may be better served with more ambitious global standards than those identified in the Education in Emergency framework described above, that encompass an international framework and a curriculum that is mobile and accredited globally. While continuing to offer education in an exceptionalist framework, an international framework would secure equal access for refugees to quality and holistic education. One challenge may be that refugees' legal status and access to employment will continue to restrict young people's potential to realize their aspirations. However, an international framework could enable refugees' improved participation and influence in the provision of education. The global curriculum framework may be available for local pupils if the host country agrees to accredit it. A few global curricula are accredited by many countries such as the

4. Lebanon has an equal number of public and private schools. The high demand for private schools is due to the dominant perception of the poor quality of public schools. 
Table 3. Potentials and Limitations of a Global and National Education Framework for Refugees

\begin{tabular}{|c|c|}
\hline Global framework & National framework \\
\hline Advantages & Advantages \\
\hline International & Strengthens local system \\
\hline $\begin{array}{l}\text { Avoids existing inequalities and problems with the local } \\
\text { educational system }\end{array}$ & $\begin{array}{l}\text { Integrates with the national curriculum } \\
\text { Respects the local context }\end{array}$ \\
\hline Can develop a more flexible framework & Gives better linkage to employment \\
\hline Avoids the nationalistic restrictions of local systems & Incorporates existing accreditation and certification \\
\hline $\begin{array}{l}\text { Overcomes the issue of accreditation and certification } \\
\text { Involves the local and refugee community }\end{array}$ & Involves the local community \\
\hline Disadvantages & Disadvantages \\
\hline Segregates & Has difficulty in addressing existing problems \\
\hline Creates a parallel system & Politicizes implementation \\
\hline Emphasizes exceptionalism & Costs more \\
\hline Widens inequalities & Depends on capacity of the local education sector \\
\hline Overlooks disadvantaged groups & Can have poor outcomes \\
\hline Costs more & Offers a rigid of national curriculum \\
\hline \multirow[t]{2}{*}{ Decontextualizes } & Creates language barriers \\
\hline & Acculturates \\
\hline
\end{tabular}

International Baccalaureate, yet they remain exclusive to an elitist student population.

An alternative to the global framework is a localized, participatory, and inclusive framework that focuses on improving the education system for all. In Lebanon, it means a further critical take on the general education provision in the country, the hurdles in the public school system, and the separation between public and private education. One challenge with this framework is the dominance of the national agenda, which might further marginalize refugees. Strengthening national systems have featured frequently in humanitarian responses and become the subject of a more dominant discourse with the localization debates and a humanitariandevelopment nexus following the World Humanitarian Summit in 2016 (Knox Clarke, 2018). In Lebanon the national agenda marginalized refugees and emphasized their exceptionality as a result of lack of political will and the humanitarian and exceptionalist framework. To combat this result, the localized framework needs to be embedded in a socially just education system where the emphasis is on participation, representation, and distribution. In Table 3 we explore the potentials and limitations of both frameworks.

There are different forms of global educational frameworks, but frameworks that are more diverse and less nationalistic, and that accommodate people on the move, are needed. Yet the degree of equity and inequality that such global frameworks produce in the national context is often questioned.
At the same time, investing in nationalistic local education frameworks often restricts quality and access for refugees.

\section{Conclusion}

There are limitations to the humanitarian education logic, as we have argued in our case study of the Lebanese experience. We acknowledge that in some situations it is difficult to move away from exceptionalist provisions accompanied by segregating and compromised education provisions. Nevertheless, we argue that in protracted displacement, investing in local, inclusive provision of education that does not impose a rigid and segregating system might achieve better educational outcomes in access and quality. A broad curriculum framework rather than a rigid and nationalist one that allows all school parties to adapt teaching and learning to respond to the needs and background of students can better respond to the inequalities in refugee crises.

\section{References}

Brun, C. (2003). Local citizens or internally displaced persons? Dilemmas of long term displacement in Sri Lanka. Journal of Refugee Studies, 16(4): 376-397. https://doi. org/10.1093/jrs/16.4.376

Brun, C. (2016). There is no future in humanitarianism: Emergency, temporality and protracted displacement. History and Anthropology, 27(4):393-410. https://doi.org /10.1080/02757206.2016.1207637 
Burde, D., Kapit, A., Wahl, A L., Guven, O., \& Skarpeteig M. I. (2017). Education in emergencies: A review of theory and research. Review of Educational Research 87(3): 619-658. https://doi.org/10.3102/0034654316671594

Chimni, B. S. (2004). From resettlement to involuntary repatriation: Towards a critical history of durable solutions to refugee problems. Refugee Survey Quarterly, 23(3): 55-73. https://doi.org/10.1093/rsq/23.3.55

Dryden-Peterson, S. (2016). Refugee education: The crossroads of globalization. Educational Researcher, 45(9): 473-482. https://doi.org/10.3102/0013189X16683398

Dryden-Peterson, S., Adelman, E., Bellino, M. J., \& Chopra, V. (2019). The purposes of refugee education: Policy and practice of including refugees in national education systems. Sociology of Education, 92(4): 346-366. https:// doi.org/10.1177/0038040719863054

Fassin, D. (2012). Humanitarian reason: A moral history of the present (Rachel Gomme, Trans.). Berkeley: University of California Press.

Ferfolja, T. (2009). The Refugee Action Support program: Developing understandings of diversity. Teaching Education, 20(4), 395-407. https://doi.org/10.1080/ 10476210902741239

Fraser, N. (2005). Reframing justice in a globalised world. New Left Review, 36, 79-88. https://newleftreview .org/issues/iiz6/articles/nancy-fraser-reframing-justicein-a-globalizing-world

Government of Lebanon \& UN. (2014). Lebanon Crisis Response Plan 2015-2016. https://reliefweb.int/sites/ reliefweb.int/files/resources/2015-2016_Lebanon_ CRP_EN.pdf

Government of Lebanon \& UN. (2018). Lebanon Crisis Response Plan 2018. International Network for Education in Emergencies (INEE). (2010). Minimum standards for education: Preparedness, response, recovery (2nd ed.). New York: INEE.

INEE. 2004. Minimum standards for education in emergencies, chronic crises and early reconstruction. Inter-Agency Network for Education in Emergencies (INEE), https:// archive.ineesite.org/en/resources/inee_minimum standards_handbook

Janmyr, M., \& Mourad, L. (2018). Modes of ordering: Labelling, classification and categorisation in Lebanon's refugee response. Journal of Refugee Studies, 31(4): 544-565. https://doi.org/10.1093/jrs/fexo42

Kagawa, F. (2005). Emergency education: A critical review of the field. Comparative Education, 41(4): 487-503. https:// doi.org/10.1080/03050060500317620

Knox Clarke, P. (2018). The state of the humanitarian system. ALNAP. https://www.alnap.org/help-library/ the-state-of-the-humanitarian-system-2018-full-report.
Lynch, K. (2006). Research and theory on equality and education. In M. T. Hallinan (Ed.), Handbook of the sociology of education (pp. 85-105). Springer us.

Ministry of Education and Higher Education (MEHE). (2014). Reaching all children with education: RACE I. Lebanon: Ministry of Education and Higher Education https:// www.mehe.gov.lb/ar/Projects/ماعل20\%مبلعـ/RACEfinalEnglish2.pdf

Ministry of Education and Higher Education (MEHE). (2016). Reaching all children with education: RACE II (20172021). Lebanon: Ministry of Education and Higher Education. http://racepmulebanon.com/index.php/featuresmainmenu-47/race2-articleNorwegian Refugee Council. (2020).

The obstacle course. Barriers to education for Syrian refugee children in Lebanon. https://www.nrc.no/resources/ reports/the-obstacle-course-barriers-to-education-forsyrian-refugee-children-in-lebanon/

RACE Project Management Unit (PMU). (2017). RACE 2 fact sheet November 2017. http://racepmulebanon.com/ images/MEHE-REC-21-11-2017FINAL_2.pdf

RACE Project Management Unit (PMU). (2018a). RACE 2 fact sheet July 2018. http://racepmulebanon.com/images/ MEHE_REC_Fact_Sheet_July_2018.pdf

RACE Project Management Unit (PMU). (2018b). RACE 2 fact sheet November 2018. Lebanese Ministry of Education. http://racepmulebanon.com/images/fact-sheet-november-2018.pdf

RACE Project Management Unit (PMU). (2019). RACE 2 fact sheet March 2019. http://racepmulebanon.com/images/ fact-sheet-march-2019.pdf

Schmidt, K. (2019). Developmentalising humanitarian space: Questioning the value of development approaches to protracted displacement. Blogpost for Refugee Hosts, July 2019. https://refugeehosts.org/2019/07/25/ developmentalising-humanitarian-space-questioningthe-value-of-development-approaches-to-protracteddisplacement/

Shuayb, S., \& Ahmad, N. (In press). The psychosocial condition of Syrian refugee and vulnerable Lebanese children amid a precarious future. Refuge.

Shuayb, M., Al Maghlouth, N., Ahmad, N., \& Held, K. (2016). An education for the future: The schooling experience of Syrian refugee children in Lebanon and Germany. Education Commission. https://lebanesestudies.com/ papers/an-education-for-the-future-the-schoolingexperience-of-syrian-refugee-children-in-lebanon-andgermany/

Shuayb, M., Makkouk, N., \& Tuttunji, S. (2014). Widening access to quality education for Syrian refugees: The role of private and NGO sectors in Lebanon. Beirut: Centre 
for Lebanese Studies. http://www.lebanesestudies.com/ wp-content/uploads/2014/o9/Widening-Access-toQuality-Education-for-Syrian-Refugees-FINAL.pdf

Sidhu, R., \& Taylor, S. (2007). Education provision for refugee youth: Left to chance? Journal of Sociology, 43, 283-300. https://doi.org/10.1177/1440783307080107

UN. (2015). Regional refugee \& resilience plan (3RP) 2015-2016: Regional strategic overview. https://reliefweb.int/sites/ reliefweb.int/files/resources/3RP-Report-Overview.pdf

UN. (2018). Regional refugee \& resilience plan 2018-2019: Regional strategic overview. UN.

UN \& Government of Lebanon. (2015). Lebanon crisis response plan 2015-16. https://www.unocha.org/sites/ dms/CAP/2015-2016_Lebanon_CRP_EN.pdf

UNHCR. (2019). Syria regional refugee response. https://data2. unhcr.org/en/situations/syria
UNHCR \& Global Education Monitoring (GEM). (2016). No more excuses. Provide education to forcibly displaced people. https://unesdoc.unesco.org/ark:/48223/ pfoooo 244847

UNICEF. (2013). A human rights and equity based situation analysis of education in Lebanon. [Unpublished].

Maha Shuayb is director of the Centre for Lebanese Studies at the Lebanese American University and an associate lecturer at University of Cambridge, Faculty of Education. She can be reached at maha.shuayb@lebanesestudies.com.

Cathrine Brun is a professor and director at the Centre for Development and Emergency Practice, School of Architecture, Oxford Brookes University. She can be reached at cbrun@ brookes.ac.uk. 